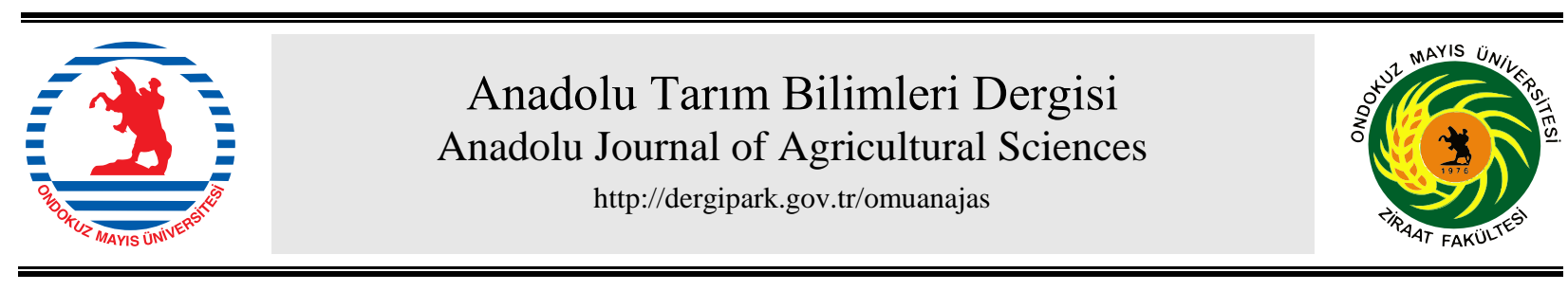

Araştırma/Research

Anadolu Tarım Bilim. Derg./Anadolu J Agr Sci 32 (2017)

ISSN: 1308-8750 (Print) 1308-8769 (Online)

doi: 10.7161/omuanajas.343719

\title{
Alternaria burnsii'nin gelişimi üzerine farklı kültürel koşulların etkisi ve rDNA-ITS sekansina dayanan filogenetik analizi
}

\author{
Harun Bayraktar ${ }^{\mathrm{a}^{*}}$, Olgac Y1lmaz ${ }^{\mathrm{a}}$, Göksel Özer ${ }^{\mathrm{b}}$ \\ ${ }^{a}$ Ankara Üniversitesi, Ziraat Fakültesi, Bitki Koruma Bölümü \\ ${ }^{b}$ Abant İzzet Baysal Üniversitesi, Ziraat ve Doğa Bilimleri Fakültesi, Bitki Koruma Bölümü \\ *Sorumlu yazar/corresponding author: bayrakta@agri.ankara.edu.tr
}

Geliş/Received 12/08/2016 Kabul/Accepted 02/10/2017

\begin{abstract}
ÖZET
Alternaria burnsii'nin neden olduğu kimyon yanıklığı birçok ülkede kimyon üretimini sınırlandıran önemli bir fungal hastalıktır. Patojen ülkemizde de hemen hemen tüm kimyon ekim alanlarında yaygın olup önemli ekonomik kayıplara neden olmaktadır. Bununla birlikte, Alternaria burnsii' nin morfolojik, fenotipik ve filogenetik özellikleri hakkında çok fazla bilgi bulunmamaktadır. Bu çalışmada Alternaria burnsii'nin miseliyal gelişimi ve sporulasyonu üzerine farklı besi ortamları ve çevresel faktörlerin etkisi araştırılmıştır. Ayrıca patojen izolatları arasındaki morfolojik farklılıklar değerlendirilmiştir. Bu amaçla patojen izolatlar, yedi farklı besi ortamı (Patates Dekstroz Agar, Patates Havuç Agar, Mısır Unu Agar, Czapek Dox Agar, Sukroz Agar, Su Agarı, Domates Suyu Agarı, V88) üzerinde iki farklı inkubasyon koşulu altında geliştirilmiştir. Değerlendirilen kültür ortamları arasında en yüksek sporulasyon değişken sıcaklık ve 1şık koşularına maruz bırakılan V88 ortamı üzerinde elde edilmiştir. Ayrıca kültür ortamı ve gelişme koşullarına bağlı olarak konidi uzunluğu, genişliği ve septa sayısı bakımından istatiksel olarak önemli farklılıklar gözlemlenmiştir. Sıcaklık patojen gelişimini etkileyen önemli bir sınırlayıcı faktör olup en iyi gelişme oran $125^{\circ} \mathrm{C}$ ' de gözlemlenmiştir. Ayrıca, UPGMA metodu ile gerçekleştirilen ITS sekansının filogenetik analizi ise test edilen tüm izolatların aynı grup içerisinde yer aldığını ve bu izolatların GenBankasından elde edilen ve farklı seksiyonları temsil eden Alternaria tür gruplarına ait izolatlardan filogenetik olarak farklı olduğunu göstermiştir. Bu sonuçların gelecekteki araştırmalar için patojen inokulumunun hazırlanmasının yanısıra patojen tespit ve tanılanması için farklı metotların geliştirilmesinde faydalı bilgiler sağlayacağı düşünülmektedir.
\end{abstract}

Effect of different cultural conditions on the growth of Alternaria burnsii and its phylogenetic analysis based on rDNA-ITS sequences

\section{ABSTRACT}

Cumin blight caused by Alternaria burnsii is an important fungal disease restricting cumin production in many countries. The pathogen is widespread in almost all cumin growing areas in Turkey and causes major economic losses. However, little information is known about morphologic, phenotypic and phylogenetic characteristics of Alternaria burnsii. In this study, the effect of different nutrient media and environmental factors on mycelial growth and sporulation of Alternaria burnsii was studied, and morphological differences among the pathogen isolates were evaluated. For this purpose, pathogen isolates were grown on seven different nutrient media (Potato Dekstrose Agar, Potato Carrot Agar, Corn Meal Agar, Czapek Dox Agar, Sucrose Agar, Water Agar, Tomato Juice Agar, V88) under two different incubation conditions. Among the culture media evaluated, the highest sporulation was obtained on V88 media exposed to the alternating temperature and light regimes. Also, the length, width and septa number of the conidia showed statistically differences depending on culture media and growing conditions. The temperature was a significant limiting factor affecting the pathogen growth. The best growth was observed at $25^{\circ} \mathrm{C}$. Phylogenetic analysis of the rDNA-ITS sequences performed by UPGMA method indicated that all tested isolates clustered in the same group and these isolates were phylogenetically distinct from the isolates of Alternaria-species groups, representing different sections retrieved from GenBank. These results could provide useful information in the pathogen inoculum

Anahtar Sözcükler:

Kimyon Fungus Besi ortamı Patojen gelişimi rDNA-ITS

Keywords: Cumin Fungus Growth medium Pathogen growth rDNA-ITS 
production for further studies as well as the development of different methods for the identification and determination of the pathogen.

\section{Giriş}

Kimyon (Cuminum cyminum L.) ülkemizde ve dünyada yaygın olarak kullanılan önemli bir tıbbi ve aromatik bitkidir. Bununla birlikte kimyon verimi farkl biyotik ve abiyotik stres faktörlerinden dolayı istenilen düzeyde olmamaktadır. Biyotik hastalık etmenleri arasında ise Alternaria burnsii' nin sebep olduğu kimyon yanıklığg önemli bir yer tutmaktadır. Hastalık etmeninin belirtileri genellikle çiçeklenme döneminde göze çarpmakta ve genç yaprakların uçlarında görülen beyazımsı nekrotik alanlar zamanla bitkilerin diğer toprak üstü kısımlarına yayılarak bitkinin yanmasına neden olmaktadır. Hastalı etmeninin \%70 varan oranlarda ürün kayıpları meydana getirdiği tespit edilmiştir (Holiday, 1980). Ülkemizde yapılan çalışmalarda ise kimyon ekim alanlarının bu hastalık etmeniyle bulaşık olduğu ve önemli derecelerde ürün kayıplarına yol açtığı bildirilmiştir (Kocatürk, 1988; Özer ve Bayraktar, 2015).

Bitki patojeni fungusların neden olduğu hastalıkların biyolojilerinin aydınlatılması, epidemiyolojilerinin belirlenmesi ve etkili kontrol yöntemlerinin geliştirilmesi amacıyla pek çok çalışma gerçekleştirilmektedir. Bununla birlikte pek çok patojen yapay ortamlarda sporulasyon yapabilmek için özel koşullara ihtiyaç duymaktadır. Özellikle Alternaria türlerinin sporulasyonu üzerinde besin kaynağı, 1şıklanma süresi ve sicaklık ana faktörler olarak görülmektedir (Rotem, 1994). Bu kapsamda pek çok Alternaria türünde yeterli sporulasyon sağlamak amacıyla farklı çalışmalar gerçekleştirilmiştir (Prasad ve ark., 2009; Naik ve ark., 2010; Ramjegathesh ve Ebenezar 2012). Bununla birlikte kimyon ekim alanlarında görülen en önemli hastalık etmeni olan $A$. burnsii'nin gelişimi için uygun koşulların belirlenmesi üzerine sınırlı sayıda çalışma bulunmaktadır (Gemawat ve Prasad, 1971).

Alternaria cinsi çok sayıda bitki patojenini içeren ve taksonomik sınıflandırması konidi özellikleri ve zincir oluşturma durumu gibi morfolojik özelliklere dayanılarak gerçekleştirilen oldukça karmaşık bir gruptur. Bu kapsamda Alternaria türlerinin taksonomik durumu sürekli olarak değișim göstermiștir (Ellis, 1971, 1976; Simmons, 1992). Alternaria cinsinin taksonomik yapısı tam olarak netleşmemekle beraber Simmons (2007) tarafindan bu cins içerisinde 275 türün bulunduğu bildirilmiştir. Alternaria burnsii ise genelde tekli, gagasız, uca doğru daralan ovoid veya elipsoid konidileri ile karakterize edilmiştir (Simmons, 2007).

Günümüzde morfolojik özellikler kullanılarak yapılan sinıflandırmalarda karşılaşılan zorluklar nedeniyle hem Alternaria cinsi içerisindeki türlerin moleküler teşhisi hem de bu cins içerisindeki funguslar arasındaki genetik akrabalıkları araştırmak için moleküler teknikler yaygın olarak kullanılmaktadır. $\mathrm{Bu}$ amaçla internal transcribed spacers (ITS), mitochondrial small-subunit (mt SSU), endopolygalacturonase (endoPG) geni, Alternaria allergen a1 (Alt al) geni, glyceraldehyde-3-phosphate dehydrogenase ( $g p d$ ) gibi farklı korunmuş bölgeler bu cins içerisindeki genetik farklılıkların ortaya konulmasında faydalı bilgiler sağlamıştır (Pryor ve Bigelow 2003; Hong ve ark., 2005; Udayashankar ve ark., 2012). Bununla birlikte kimyonda sorun olan A. burnsii'nin genetik yapıs1 hakkında çok fazla çalışma bulunmamaktadır (Özer ve Bayraktar, 2015).

Ayrıca aynı tür içerisindeki izolatlar arasında görülen morfolojik ve fizyolojik farklılıklar bu türün patojenik ve genetik farklılıklarını da yansıtabilmektedir. Bu kapsamda yapılan çalışmalarda farklı Alternaria türleri içerisinde yüksek derecede genetik ve patojenik farklılıkların bulunduğu tespit edilmiştir (Castro ve ark., 2000; Shahzad, 2003). Bu çalışma kapsamında ise kimyonda görülen yanıklık etmeninin farklı izolatları arasındaki morfolojik ve fizyolojik farklılıkların belirlenmesi, farklı seksiyonları temsil eden Alternaria tür grupları ile filogenetik ilişkisinin incelenmesi ve sporulasyonu için uygun ortam koşullarının tespit edilmesi amaçlanmıştır.

\section{Materyal ve Yöntem}

\subsection{Materyal}

Çalışmada materyal olarak ülkemizin en önemli kimyon ekim alanları olan Ankara ve Konya illerindeki farklı kimyon ekim alanlarından elde edilen beş adet $A$. burnsii izolat1 (Kon1, Kon2, Kon3, Ank1, Ank2) kullanılmıştır. Patojen izolatlar Patates Dekstroz Agar (PDA) ortamı üzerinde $23 \pm 2^{\circ} \mathrm{C}^{\prime} \mathrm{de} 15$ gün süreyle geliştirilmiştir. İzolatların patojenisite testleri ise yerel kimyon çeşidi üzerinde gerçekleştirilmiş ve \%90'nın üzerinde patojen oldukları tespit edilmiştir (Bayraktar ve ark. 2013).

\subsection{Yöntem}

\subsubsection{Alternaria burnsii İzolatları Arasındaki Morfolojik Farklılıkların Belirlenmesi}

A.burnsii'nin morfololojik özelliklerinin belirlenmesi amaciyla tüm izolatlar farklı besin ortamlarında ve sıcaklık-ışık koşullarında inkübasyona bırakılmış ve izolatların sporulasyon miktarı, konidi büyüklükleri, bölme sayısı ve misel genişliği belirlenmiştir. $\mathrm{Bu}$ amaçla PDA ortamında geliştirilen her bir kültürlerden alınan $5 \mathrm{~mm}$ çapındaki agar diskleri PDA, Su Agar (\%1'lik), Czapek-Dox Agar, Misır Unu Agar, Sukroz Agar (sukroz 20 g,CACO 30 g, agar $20 \mathrm{~g}$ $\mathrm{l}^{-1}$ ), Domates Suyu Agarı (domates suyu $200 \mathrm{ml}$, CaCO3 $3 \mathrm{~g}$, agar $\left.20 \mathrm{~g} \mathrm{l}^{-1} \mathrm{pH}: 6.5\right)$, Patates Havuç Agar (PCA, havuç $20 \mathrm{~g}$, patates $20 \mathrm{~g}$, agar $15 \mathrm{~g} \mathrm{~L}^{-1}$ ) ve V88 
(domates $400 \mathrm{~g}$, havuç $100 \mathrm{~g}$, pancar $60 \mathrm{~g}$, marul $20 \mathrm{~g}$, kereviz $10 \mathrm{~g}$, maydanoz $10 \mathrm{~g}$, tere $10 \mathrm{~g}$, 1spanak $10 \mathrm{~g} \mathrm{~L}$ $\left.{ }^{1}\right)$ ortamlarına aktarılmıştır. Bu şekilde inokule edilen Petri kapları iki farklı şekilde inkübe edilmiştir.

a-Tüm izolatlar farklı ortamlar üzerinde $23 \pm 2{ }^{\circ} \mathrm{C}$ ' de standart 12 saat 1 şık-12 saat karanlık periyot içeren inkübasyon odasında 15 gün süreyle geliştirilmiştir.

b- Aynı ortamlara aşılanan Petri kapları değişken 1şık ve sicaklık (5 gün $22 \pm 2{ }^{\circ} \mathrm{C}$ ' de karanlık, 1 gün $18 \pm 2$ ${ }^{\circ} \mathrm{C}$ ' de aydınlık, ve tekrar 4 gün karanlıkta inkubasyon) koşullarında geliş̧irilmiştir.

Her iki inkubasyon periyodundan sonra Petri kaplarına $20 \mathrm{ml}$ steril saf su ilave edilerek steril bir spatül yardımı ile fungus sporları agar yüzeyinden kazınarak süzülmüştür. Hazırlanan bu spor süspansiyonlarının konsantrasyonu thoma lamı ile sayım yapılarak belirlenmiştir. İzolatlar arasındaki morfolojik özelliklerin belirlenmesi amaciyla lam üzerindeki farklı alanlardan her bir izolata ait 30 konidinin en, boy oranları, bölme sayıları, misel genişliği $(\mu \mathrm{m})$ 40x büyütmede 1 şı mikroskobunda (Leica DM1000) belirlenmiştir.

\subsubsection{Sicaklı̆̆ın Kültür Gelişsimi Üzerine Etkilerinin Belirlenmesi}

Kültür gelişimi üzerine sıcaklığın etkisini belirlemek için tüm izolatlar PDA ortamı üzerine aşılanmış ve Petri kapları 20,25 ve $30^{\circ} \mathrm{C}$ ' de 12 saat $1 s ̧ 1 \mathrm{k}-12$ saat karanlık periyot içeren inkübasyon odasında 7 gün süreyle geliştirilmiştir. İnkubasyondan sonra her bir Petri kabındaki gelişme oranı iki taraftan çapraz olarak ölçülerek gelişme oranları belirlenmiştir.

Denemeler 3 tekerrürlü olarak gerçekleştirilmiş ve elde edilen değerler Minitab ve MSTAT istatistik programları kullanılarak Varyans Analizi ve Duncan Çoklu Karşılaştırma Testi $\quad(\mathrm{P}>0.05) \quad$ ile değerlendirilmiştir.

\subsubsection{Fungus Kültürlerinden DNA İzolasyonu}

$\mathrm{Bu}$ amaçla Potato Dextrose Broth (PDB) ortamında geliştirilen fungus miselleri sivı nitrojen içerisinde ezilmiş ve ektraksiyon bufferı (200 mM Tris- $\mathrm{HCl}$ pH:8.5, $25 \mathrm{mM} \mathrm{NaCl}, 25 \mathrm{mM}$ EDTA, \% 0.5 SDS) ile süspanse edilerek $65{ }^{\circ} \mathrm{C}^{\prime}$ de 1 saat inkübasyona bırakılmıştır. İnkübasyondan sonra örneklere eşit hacim phenol:chloroform eklenerek 13.000 g' de 1 saat santrifüj yapılmış ve RNase A ile tekrar inkübe edilmiştir. Daha sonra örneklere chloroform: isoamylalcohol ilave edilerek santrifüj edilmiştir. Örneklere isopropanol eklenerek DNA çöktürülmüş ve steril bi-destile su ile süspanse edilerek $-20^{\circ} \mathrm{C}$ 'de saklanmıştır (Reader ve Broda, 1985).

\subsubsection{Alternaria burnsii Izolatlarınin rDNA-ITS Bölgesinin Sekans Analizi}

Alternaria burnsii izolatlarını ribosomal DNA üzerindeki ITS bölgesinin amplifikasyonu için White ve ark. (1990) tarafindan belirlenen ITS1 (5'-TCC GTA GGT GAA CCT GCG G-3') ve ITS4 (5'-TCC TCC GCT TAT TGA TAT GC-3') primerleri kullanılmıştır. PCR reaksiyonu, $200 \mu \mathrm{M}$ dNTPs, $0.4 \mu \mathrm{M}$ primer, 10X reaksiyon buffer1, $1.5 \mathrm{mM} \quad \mathrm{MgCl}_{2}, 1.5 \mathrm{U}$ Taq DNA polymerase (Thermo Scientific) ve 30-50 ng fungal DNA içeren $50 \mu \mathrm{l}$ ' lik hacimlerde gerçekleştirilmiştir. DNA amplifikasyonu ise $94{ }^{\circ} \mathrm{C}^{\prime} \mathrm{de} \quad 2 \mathrm{dk}$. ilk denatürasyon, $94{ }^{\circ} \mathrm{C}^{\prime}$ de $1 \mathrm{dk}$., $57^{\circ} \mathrm{C}^{\prime}$ de $30 \mathrm{~s}, 72^{\circ} \mathrm{C}$ 'de 30 s 35 döngü ve $72{ }^{\circ} \mathrm{C}^{\prime}$ de $10 \mathrm{dk}$. olacak şekilde programlanan thermal cycyler'da yapılmıştır.

Daha sonra elde edilen PCR ürünleri kontrol amaciyla, \%1' lik agaroz jelde elektroforetik olarak ayrılmıştır (Sambrook ve ark., 1989). Elde edilen PCR ürünlerinden aynı primerler kullanılarak çift yönlü sekans dizisi elde edilmiş ve sekans bilgisi DNAStar ve Mega5 (Tamura ve ark., 2011) programları kullanılarak analiz edilmiştir. Elde edilen sekanslar ClustalW metodu ile hizalanmış ve UPGMA metoduna göre 1000 permütasyonlu bootstrap analizi ile dendogram oluşturulmuştur. Ayrıca farklı Alternaria seksiyonlarını temsil eden türlere ait sekans bilgileri Gen Bankasından alınarak çalışmalara dâhil edilmiştir (Lawrence ve ark., 2013).

\section{Bulgular ve Tartışma}

Alternaria burnsii izolatlarının gelişimi için uygun besin ve gelişme koşullarının belirlenmesi amacıyla yapılan çalışmalarda 7 farklı ortam ve 2 farklı gelişme koşulu değerlendirilmiş olup, gelişme koşullarının farklı ortamlardaki sporulasyon üzerinde oldukça etkin olduğu görülmüştür (Çizelge 1). Yapılan çalışmada 12 saat aydınlık/karanlık koşullarında inkube edildiğinde izolatların sadece PCA ve Sukroz Agar ortamlarında yeterli miktarda sporulasyon yaptığı görülmüştür. PCA ortamındaki sporulasyon miktar1 $3.25-5 \times 10^{4}$ spor $\mathrm{ml}^{-1}$ arasında değişir iken bu oran Sukroz Agar ortamında 1.12-2.62 $\times 10^{4}$ spor $\mathrm{ml}^{-1}$ olarak bulunmuştur. Test edilen V88 ve Domates Suyu Agar ortamlarında ise çok az spor oluşumu görülmekle birlikte thoma lamında tespit edilememiştir. PDA, Su Agarı, Mısır unu agar ve Czapek-Dox Agar ortamlarında ise spor oluşumu gözlenmemiştir. İzolatlar değişken inkubasyon koşullarında (5 gün $22 \pm 2{ }^{\circ} \mathrm{C}$ ' de karanlık, 1 gün $18 \pm 2^{\circ} \mathrm{C}^{\prime}$ de aydınlık ve tekrar 4 gün karanlıkta inkubasyon) inkube edildiğinde sadece V88 ortamında etmen sporlar1 tespit $\left(5.37-7.25 \times 10^{4}\right.$ spor $\left.\mathrm{ml}^{-1}\right)$ edilebilmiştir. PCA ve Domates Suyu Agar ortamlarında ise bazı izolatlarda çok az spor oluşumu görülmekle birlikte thoma lamında tespit edilememiştir. Ayrıca 12 saat aydınlık/karanlık koşullarında spor tespit edilen Sukroz agar ortamı ile PDA, Su Agarı, Misır Unu Agar ve Czapek-Dox Agar ortamlarında bu inkubasyon koşullarında sporulasyon görülmemiştir. 
Çizelge 1. Alternaria burnsii izolatlarının farklı inkubasyon koşulları ve besin ortamlarında geliştirilmesi sonucu elde edilen spor miktarları $\left(\times 10^{4}\right)$

\begin{tabular}{|c|c|c|c|c|c|c|c|c|c|c|}
\hline & \multicolumn{5}{|c|}{12 saat aydınlık/karanlık } & \multicolumn{5}{|c|}{ Değişken inkubasyon koşulları } \\
\hline Besin ortam 1 & Ank1 & Ank2 & Kon1 & Kon3 & Kon2 & Ank1 & Ank2 & Kon1 & Kon3 & Kon2 \\
\hline Su Agarı & - & - & - & - & - & - & - & - & - & - \\
\hline PDA & - & - & - & - & - & - & - & - & - & - \\
\hline Misır Unu Agarı & - & - & - & - & - & - & - & - & - & - \\
\hline Czapek-Dox Agar & - & - & - & - & - & - & - & - & - & - \\
\hline PCA & 4.375 & 5 & 3.375 & 4.75 & 3.25 & $\mathrm{R}$ & - & $\mathrm{R}$ & $\mathrm{R}$ & $\mathrm{R}$ \\
\hline Sukroz Agar & 1.125 & 2.625 & 1.125 & 1.625 & 2.625 & - & - & - & - & - \\
\hline V88 & - & - & $\mathrm{R}$ & $\mathrm{R}$ & $\mathrm{R}$ & 6.25 & 7.25 & 7 & 5.375 & 5.5 \\
\hline Domates Suyu Agarı & $\mathrm{R}$ & $\mathrm{R}$ & $\mathrm{R}$ & $\mathrm{R}$ & $\mathrm{R}$ & $\mathrm{R}$ & - & - & $\mathrm{R}$ & $\mathrm{R}$ \\
\hline
\end{tabular}

$\mathrm{R}$ : Thoma lamında tespit edilemeyecek düzeyde az spor oluşumu

Alternaria burnsii izolatlarının sporulasyon yaptığı ortamlardan yapılan ölçümlerde de yine ortam koşullarına göre hem spor boyunda hem de bölme sayılarında farklılık görülmüştür (Çizelge 2). Spor büyüklükleri bakımından incelendiğinde V88 ortamında geliștirilen izolatların genelde diğer ortamlara göre daha büyük olduğu gözlemlenmiştir. Bu ortamda en büyük spor gelişimi Kon1 izolatında görülür iken en küçük spor Kon2 izolatında görülmüştür. V88 ortamında geliştirilen Kon2 izolatı hariç tüm izolatların spor büyüklüklerinin istatistiki olarak diğer ortamlara göre farklı olduğu bulunmuştur. Benzer şekilde PCA ve
Sukroz Agar ortamında geliştirilen izolatların spor büyüklükleri arasında istatistiki olarak önemli farklılıklar görülmüştür. Farklı besin ortamlarının izolatların bölme sayıları üzerine etkileri incelendiğinde PCA ortamındaki Kon2 izolatı hariç V88 ortamında geliştirilen diğer izolatlarda, spor büyüklüğü ile orantılı olarak bölme sayısının daha fazla olduğu görülmüsstür. İzolatlar dikine bölme sayıları bakımından kendi içlerinde karşılaştırıldığında ise sadece V88 ortamında geliştirilen Kon1 izolatında istatistiki olarak farklılık bulunmuştur.

Çizelge 2. Sporulasyon tespit edilen ortamlardaki izolatların spor boyları ve bölme sayıları

\begin{tabular}{|c|c|c|c|c|c|c|c|c|c|c|c|c|}
\hline \multirow{3}{*}{ İzolatlar } & \multicolumn{4}{|c|}{$\begin{array}{c}\text { PCA } \\
\text { (12 saat aydınlık/karanlık) }\end{array}$} & \multicolumn{4}{|c|}{$\begin{array}{c}\text { Sukroz agar } \\
\text { (12 saat aydınlık/karanlık) }\end{array}$} & \multicolumn{4}{|c|}{$\begin{array}{l}\text { V88* } \\
\text { inkubasyon koșulları) }\end{array}$} \\
\hline & \multicolumn{2}{|c|}{ Bölme Sayıs1 } & \multicolumn{2}{|c|}{$\begin{array}{c}\text { Spor } \\
\text { büyüklüğü } \\
(\mu \mathrm{m})\end{array}$} & \multicolumn{2}{|c|}{ Bölme Sayısı } & \multicolumn{2}{|c|}{$\begin{array}{c}\text { Spor } \\
\text { büyüklüğ̈ü } \\
(\mu \mathrm{m})\end{array}$} & \multicolumn{2}{|c|}{ Bölme Sayısı } & \multicolumn{2}{|c|}{$\begin{array}{c}\text { Spor } \\
\text { büyüklüğ̈ü } \\
(\mu \mathrm{m})\end{array}$} \\
\hline & $\begin{array}{l}\text { Dikine } \\
\text { bölme }\end{array}$ & $\begin{array}{l}\text { Enine } \\
\text { bölme }\end{array}$ & Boy x Ge & nişlik & $\begin{array}{l}\text { Dikine } \\
\text { bölme }\end{array}$ & $\begin{array}{l}\text { Enine } \\
\text { bölme }\end{array}$ & Boy x C & enişlik & $\begin{array}{l}\text { Dikine } \\
\text { bölme }\end{array}$ & $\begin{array}{l}\text { Enine } \\
\text { bölme }\end{array}$ & Boy x G & nişlik \\
\hline Kon1 & $3.9 \mathrm{~b}$ & 1.15 & $41.3 \mathrm{~b}$ & 14.1 & $4.45 b$ & 1.15 & $33.1 \mathrm{c}$ & 12.8 & $5.2 \mathrm{a}$ & 1.4 & $52.7 \mathrm{a}$ & 16.5 \\
\hline Kon2 & $4.95 \mathrm{a}$ & 1.55 & $41.8 \mathrm{a}$ & 14.2 & $4.5 \mathrm{a}$ & 1.35 & $43.2 \mathrm{a}$ & 14.4 & $4.6 \mathrm{a}$ & 1.8 & $46.1 \mathrm{a}$ & 16.2 \\
\hline Kon3 & $4.55 \mathrm{a}$ & 1.35 & $42.5 b$ & 16.5 & $4.4 \mathrm{a}$ & 1.35 & $42.1 \mathrm{~b}$ & 15.6 & $4.9 \mathrm{a}$ & 1.5 & $52.4 \mathrm{a}$ & 16.6 \\
\hline Ank1 & $4.25 \mathrm{a}$ & 1.4 & $47 \mathrm{a}$ & 19.1 & $4.5 \mathrm{a}$ & 1.35 & $41.6 b$ & 13.7 & $4.7 \mathrm{a}$ & 1.65 & $46.8 \mathrm{a}$ & 15.4 \\
\hline Ank2 & $4.3 \mathrm{a}$ & 1.1 & $46.5 b$ & 15.5 & $4.35 \mathrm{a}$ & 1.4 & $42.2 \mathrm{c}$ & 14 & $4.8 \mathrm{a}$ & 1.6 & $52.2 \mathrm{a}$ & 18.7 \\
\hline
\end{tabular}

*Aynı harf ile temsil edilen ortalamalar arasındaki fark istatistiki olarak önemsizdir.

Alternaria burnsii için uygun gelişme koşullarının belirlenmesi üzerine sınırlı çalışma bulunmaktadır. Farklı şeker ve amino asitlerin A. burnsii' nin sporulasyonu ve misel gelişimi üzerinde etkisini araştıran Gemawat ve Prasad (1971) patojen için en iyi karbon kaynağının maltoz olduğunu belirtmiş olup fenilalanin, aspartik asit ve DL-serin amino asitlerinin de sporulasyon üzerinde oldukça etkili olduğunu tespit etmişlerdir. $\mathrm{Bu}$ çalışmada kullanılan ortamlar karşılaştırıldığında ise besin çeşitliliği diğer ortamlara göre daha yüksek olan V88 ortamında izolatların daha yüksek seviyede sporulasyon yaptığ 1 ve spor gelişiminin daha iyi olduğu görülmüştür. Bununla birlikte konidi oluşumu tespit edilemeyen bazı ortamlardaki şeker miktarının konidi oluşumu üzerinde etkili olabileceği de düşünülmektedir. Alternaria solani ile yapılan çalışmalarda fungus konidiofor oluşturabilmek için bir karbon kaynağına ihtiyaç duyar iken yüksek miktardaki şekerin konidi üretimini engellediği tespit edilmiştir (Waggoner ve Horsfall, 1969). Bu sonuç V88 ortamına sukroz ilave edildiğinde aynı fungusun sadece konidiofor oluşturduğunu tespit eden Rodrigues ve ark., (2010)'1 tarafından da doğrulanmıştır. Bu kapsamda Alternaria türlerinin sporulasyonu için besi ortamına $\mathrm{CaCO}_{3}$ ilavesi yaygın olarak kullanılmıştır (Naik ve ark. 2010; Rodrigues ve ark., 2010).

Değişken inkubasyon koşullarının özellikle ışıklanmanın Alternaria türlerinin sporulasyonu 
üzerinde önemli derecede etkisi olduğu bilinmekte olup konidiofor oluşumunun aydınlık koşullarda, konidi oluşumunun ise karanlık koşullarda teşvik edildiği farklı araştırıcılar tarafinda bildirilmiştir (Lukens 1960; Douglas 1972). Bu çalışmada da 1şıklanma süresinin patojenin vejatatif gelişimini tamamlaması ve yeterli seviyede konidi ve konidiofor oluşturabilmesi açısından önemli rol oynadığ 1 düşünülmektedir. Farklı Alternaria türlerinin gelişimi ve sporulasyonu için uygun koşulların belirlenmesi amacıyla yapılan çalışmalarda da benzer sonuçlar elde edilmiştir. Altenaria solani'nin sporulasyonunu teşvik etmek amaciyla farklı besin, sıcaklık ve 1şıklanma sürelerini test eden Benlioğlu ve Delen (1996) değişken sicaklık ve 1şıklanma koşullarının patojen sporulasyonu açısından oldukça önemli olduğunu en iyi sporulasyonun bu çalışmadakine benzer bir sıcaklık-1şık kombinasyonunda elde edilebildiğini bildirmiştir. Domateste sorun olan $A$. solani izolatları üzerinde benzer bir çalışma gerçekleştiren Naik ve ark. (2010) test edilen 4 izolat arasında konidi özellikleri ve hif genişliği bakımından farklılıkların bulunduğunu belirtmiştir. Ayrıca farklı besin ortamları, sıcaklık, nem ve 1şıklanma sürelerinin A. solani' nin sporulasyonu ve gelişme oranı üzerinde etkili olduğunu tespit etmişlerdir. Bu çalışmada da izolatların farklı ortamlardaki misel genişlikleri incelenmiş ve 5.06-6.05 $\mu \mathrm{m}$ arasında değiştiği tespit edilmiştir. Ancak gelişme koşullarına göre izolatlar arasında misel genişliği bakımından önemli bir farklılık görülmemiştir. Pamukta önemli ekonomik kayıplara neden olan A. macrospora'nın 10 izolatı arasındaki morfolojik, patojenik ve moleküler farklılıkları araştıran Jadhav ve ark. (2011) misel genişliği, konidi büyüklüğü ve septa sayısı bakımından önemli morfolojik farklılıkların bulunduğunu ve izolatlar arasında moleküler olarak iki faklı grubun olduğunu bildirmişlerdir. Benzer şekilde soğanda yaprak yanıklığına sebep olan A. alternata'nın 10 izolatı arasındaki kültürel farklılıkları araştıran Ramjegathesh ve Ebenezar (2012) ise konidi büyüklüğü ve sporulasyon bakımından izolatlar arasında farklılıklar tespit etmişlerdir. Ayrıca kültür ortamı ve pH'ya bağlı olarak izolatların miseliyal gelişim oranları arasında farklılıkların bulunduğu görülmüştür.

Farklı inkübasyon derecelerinin A. burnsii izolatlarının kültür gelişimi üzerine etkilerini belirlemek için yapılan çalışmalarda ise tüm izolatlar PDA ortamına aşılanmış ve 20,25 ve $30{ }^{\circ} \mathrm{C}^{\prime}$ lerde 7 gün süreyle geliştirilerek kültür çapları ölçülmüştür (Çizelge 3). İzolatlar $20{ }^{\circ} \mathrm{C}$ de geliştirildiğinde ortalama 3.834 $\mathrm{cm}$ 'lik bir gelişime tespit edilmiştir. En yavaş gelişen Ank1 izolatı $(3.4 \mathrm{~cm})$ hariç diğer izolatlar arasında önemli bir farklılık görülmemiştir. İzolatlar $25{ }^{\circ} \mathrm{C}$ geliştirildiğinde ise ortalama $4.254 \mathrm{~cm}$ ile oldukça hızlı bir gelişim göstermişlerdir. Kon2 en hızlı gelişen izolat $(4.6 \mathrm{~cm})$ olur iken Kon3 (3.97) en yavaş gelişen izolat olmuştur. İzolatlar $30{ }^{\circ} \mathrm{C}$ de inkube edildiğinde kültür gelişimleri büyük ölçüde azalmakla birlikte aralarındaki fark istatistiki olarak önemli bulunmuştur. Naik ve ark.
(2010), A. solani' nin optimum gelişme sicaklığının 25 ${ }^{\circ} \mathrm{C}$ olduğunu, en iyi gelişme oranı ve sporulasyonun $\% 100$ nispi nemde sağlandığını bildirmişlerdir. Alhussaen (2012), domateste erken yanıklık etmeni olan A. solani izolatlarının optimum gelişme sıcaklığının 30 ve $25{ }^{\circ} \mathrm{C}$ olduğunu ve bu sıcaklıklar arasında istatistiki bir farkın bulunmadığını belirtmişlerdir. Ayrıca bu izolatların gelişme oranları arasında önemli farklılıklar gözlemlenmiştir.

Çizelge 3. Farklı sıcaklıkların Alternaria burnsii izolatlarının kültür gelişimi $(\mathrm{cm})$ üzerine etkilerinin belirlenmesi

\begin{tabular}{|c|c|c|c|}
\hline İzolatlar $^{*}$ & $20^{\circ} \mathrm{C}$ & $25^{\circ} \mathrm{C}$ & $30^{\circ} \mathrm{C}$ \\
\hline Kon1 & $3.78 \mathrm{ab}$ & $4.17 b c$ & $1.80 \mathrm{bc}$ \\
\hline Kon2 & $3.93 \mathrm{a}$ & $4.60 \mathrm{a}$ & $1.97 \mathrm{ab}$ \\
\hline Kon3 & $3.88 \mathrm{a}$ & $3.97 \mathrm{c}$ & $1.73 \mathrm{c}$ \\
\hline Ank1 & $3.40 \mathrm{~b}$ & $4.23 b$ & $2.10 \mathrm{a}$ \\
\hline Ank2 & $4.18 \mathrm{a}$ & $4.30 \mathrm{~b}$ & $1.83 \mathrm{bc}$ \\
\hline Ortalama & 3.834 & 4.254 & 1.886 \\
\hline
\end{tabular}

*Aynı harf ile temsil edilen ortalamalar arasındaki fark istatistiki olarak önemsizdir.

Alternaria burnsii izolatlarının ITS1/4 primerleri kullanılarak yapılan PCR analizi sonucunda ise tüm izolatlardan yaklaşık 530 bp büyüklüğünde tek bir band çoğaltılmıştır (Şekil 1). Sekans analizinde ise tüm izolatlardan 500 bp değerlendirmeye alınmış ve Gen Bankasından elde edilen ve farkl seksiyonları temsil eden Alternaria türlerine ait sekanslarla birlikte dendogram oluşturulmuştur (Şekil 2). Elde edilen dendogram incelendiğinde tüm $A$. burnsii izolatlarının genetik olarak benzer olduğu ve $\% 100$ bootstrap değeri ile aynı genotip içerisinde yer aldığı görülmüştür. Ayrıca bu izolatların en fazla $A$. solani ile benzerlik gösterdiği bununla birlikte farklı seksiyonları temsil eden diğer Alternaria türlerinden oldukça farklı oldukları görülmüştür.

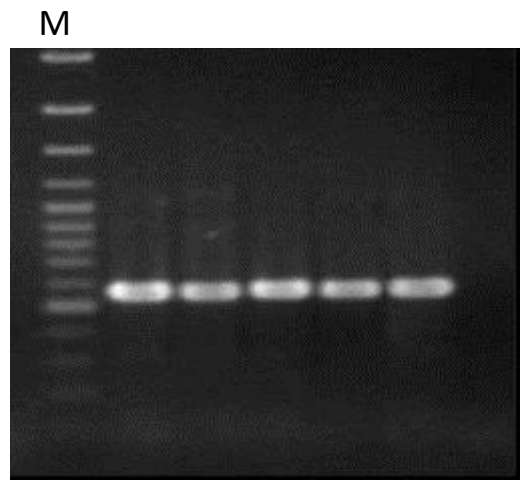

Şekil 1. Alternaria burnsii izolatlarının ITS1/4 primeri ile çoğaltılması sonucu elde edilen 530 bp'lik PCR ürünü. M: Markör Gene Ruler 100 bp DNA ladder (Thermo Scientific) 


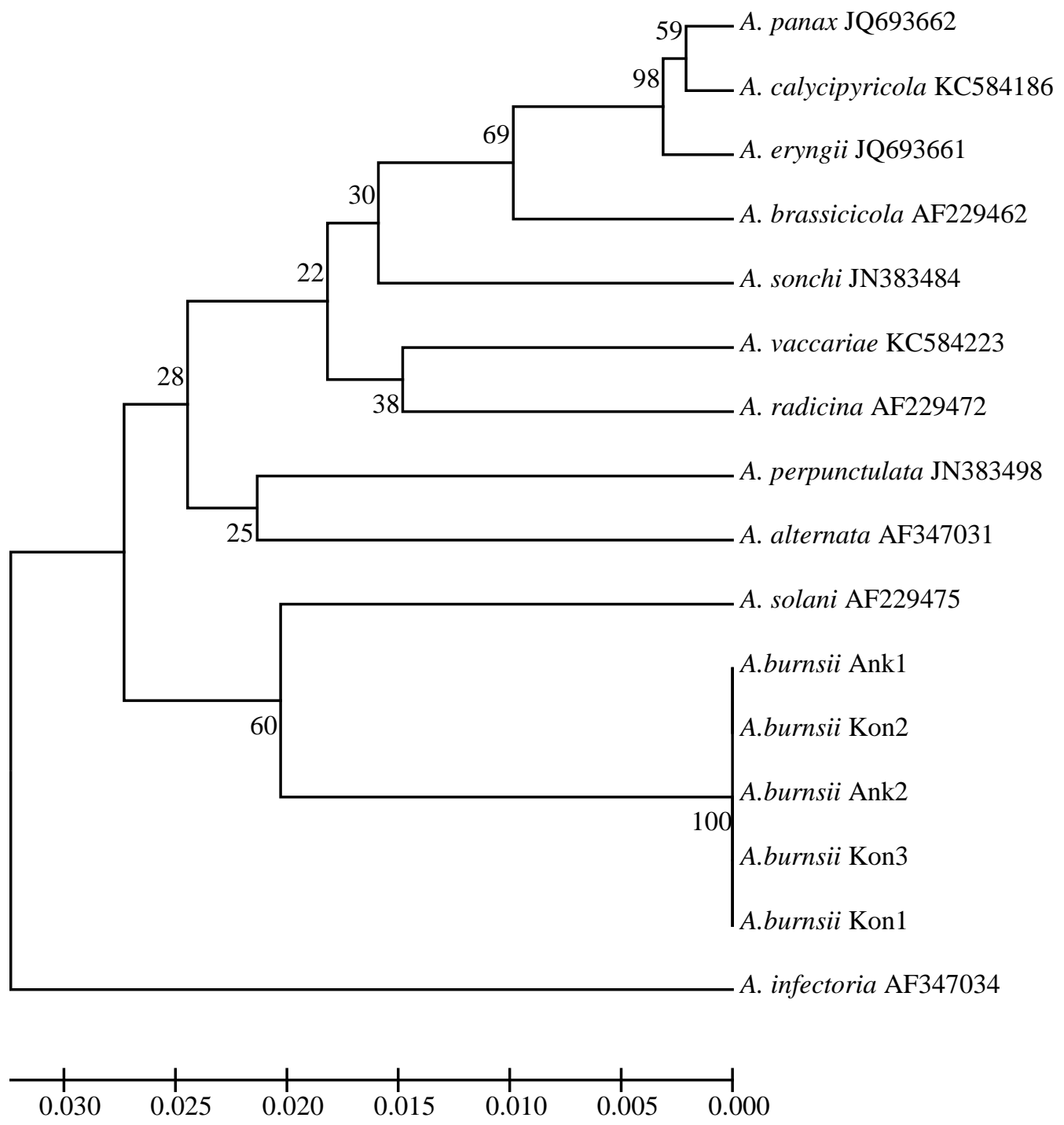

Şekil 2. Alternaria burnsii ve farklı Alternaria seksiyonlarını temsil eden türlerin rDNA-ITS bölgesindeki sekans farklılıklarını gösteren UPGMA dendogramı

\section{Sonuç}

Ülkemiz kimyon ekim alanlarında görülen en önemli hastalıklardan birisi Alternaria burnsii'nin neden olduğu kimyon yanıklığıdır. Diğer bitki patojenlerinde olduğu gibi bu hastalık etmeninin morfolojik, kültürel ve genetik özelliklerinin bilinmesi etmene karşı etkili mücadele yöntemlerinin geliştirilebilmesi ve ürün kayıplarının engellenmesi açısından oldukça önem taşımaktadır. Ülkemizde bu patojen ile ilgili çok fazla çalışma bulunmamakta ve bu sebeple patojenin biyolojisi ve mücadelesi ile ilgili çalışmalara ihtiyaç duyulmaktadır. $\mathrm{Bu}$ eksiklikleri gidermek amaciyla yapılan bu çalışmadan elde edilen sonuçlar A. burnsii izolatlarının gelişimi için en uygun ortamın V88 ortamı olduğunu, optimum gelişmenin $25^{\circ} \mathrm{C}$ de sağlandığı ve izolatların değişken inkubasyon koşulları altında tutulmasının konidiofor ve konidi oluşumunun teşvik edilmesi açından önemli olduğunu göstermiştir. Ayrıca izolatlar arasında konidi özellikleri ve gelişme hızları bakımından önemli farklılıkların bulunduğu görülmüştür. A. burnsii izolatlarının ITS bölgesinin sekans analizinde ise izolatların genetik olarak benzer olduğu, bununla birlikte diğer Alternaria türlerinden oldukça farklı oldukları görülmüştür. Farklı Alternaria tür grupları ile patojen izolatları arasındaki genetik farklılığın bu fungus türünün tespit edilmesinde PCR' a dayalı hızlı tanı ve tespit yöntemlerinin geliştirilmesinde oldukça faydalı olacağı düşünülmektedir. Bu patojen için uygun gelişme koşullarının belirlenmesinin ve genetik karakterizasyonun yapılmasının bu hastalık etmeni ile yapılacak diğer çalışmalarda araştırıcılara faydalı olacağı düşünülmektedir. 


\section{Kaynaklar}

Alhussaen, K.M., 2012. Altemaria solani isolated from Tomato in Jordan Valley. Research Journal of Biological Sciences, 7(8): 316-319.

Bayraktar, H., Özer, G., Oksal, E., 2013. Phylogenetic analysis of Alternaria spp. and related fungi associated with cumin blight based upon analysis of nuclear ITS and Alt al gene sequences. 1st Mediterranean Symposium on Medicinal and Aromatic Plants (MESMAP-2013) April 17-20, The Northern Cyprus.

Benlioğlu, S., Delen, N., 1996. Studies on the Sporulation of the Early Blight Agent [Alternaria solani (Ell. and Mart.) Jones and Grout] of Tomatoes. Journal of Turkish Phytopathology, 25: 23-28.

Castro, M.E.A., Zambolim, L., Chaves, G.M., Cruz, C.D., Matsuoka, K., 2000. Pathogenic variability of Alternaria solani, the causal agent of tomato early blight. Summa Phytopathologica, 26:24-28.

Douglas, D.R., 1972. The effect of light and temperature on the sporulation of different isolates of Alternaria solani. Canadian Journal of Botany, 50: 629-634.

Ellis, M.B., 1971. Dematiaceous Hyphomycetes. CMI, Kew, Surrey, England, pp. 1-608.

Ellis, M.B., 1976. More Dematiaceous Hyphomycetes. CMI, Kew. Surrey, England, pp. 1-507.

Gemawat, P.D., Prasad, N., 1971. Alternaria blight of Cuminum cyminum L. Proceedings of the Indian National Science Academy: Biological Sciences, 38: 3843.

Holiday, P., 1980. Fungus Diseases of Tropical Crops. Cambridge University Press.

Hong, S.G., Cramer, R.A., Lawrence, C.B., Pryor, B.M. 2005. Alt a1 allergen homologs from Alternaria and related taxa: analysis of phylogenetic content and secondary structure. Fungal Genetics and Biology, 42:119-129.

Jadhav, B.M., Perane, R.R., Kale, A.A., Pawar, N.B., 2011. Morphological, pathological and molecular variability among Alternaria macrospora isolates causing leaf blight of cotton. Indian Phytopathology, 64(3): 54-257.

Kocatürk, S., 1988. The important cumin diseases in Central Anatolia. Journal of Turkish Phytopathology 17:121.

Lawrence, D.P., Gannibal, P.B., Peever, T.L., Pryor, B.M., 2013. The sections of Alternaria: formalizing speciesgroup concepts. Mycologia, 105: 530-546.

Lukens, R.J., 1960. Conidial production from filter paper culture of Helminthosporium vagans and Alternaria solani. Phytopathology, 50: 867-868.

Naik, M. K., Prasad, Y., Bhat, K. V., Rani, G. D., 2010. Morphological, physiological, pathogenic and molecular variability among isolates of Alternaria solani from tomato. Indian Phytopathology, 63(2): 168-173.

Özer, G., Bayraktar, H., 2015. Determination of fungal pathogens associated with Cuminum cyminum in Turkey. Plant Protection Science, 51:74-79.

Prasad, M.S., Sujatha, L.M., Rao, S.C., 2009. Analysis of cultural and genetic diversity in Alternaria helianthi and determination of pathogenic variability using wild helianthus species. Journal of Phytopathology, 157:609617.

Pryor, B.M., Bigelow, D.M., 2003. Molecular characterization of Embellisia and Nimbya species and their relationship to Alternaria, Ulocladium and Stemphylium. Mycologia, 95(6):1141-1154.
Ramjegathesh, R., Ebenezar, E.G., 2012. Morphological and physiological characters of Alternaria alternata causing leaf blight disease of onion. International Journal of Plant Pathology, 3(2):34-44.

Reader, U., Broda, P., 1985. Rapid preparation of DNA from filamentous fungi. Lett. Appl. Microbiol., 1: 17-20.

Rodrigues, T.T., Maffia, L.A., Dhingra, O.D., Mizubuti, E.S., 2010. In vitro production of conidia of Alternaria solani. Tropical Plant Pathology, 35: 203-212.

Rotem, J., 1994. The genus Alternaria: biology, epidemiology and pathogenicity. The American Phytopathological Society, St. Paul, Minnesota.

Sambrook, J., Fritsch, E.F., Maniatis, T., 1989. Molecular cloning: A Laboratory manual, 2nd edn. New York, Cold Spring Harbor Laboratory Press, pp. 1659.

Shahzad, A., 2003. Studies on Alternaria leaf blotch of apple in Kashmir (Doctoral dissertation, Ph. D.(Agric.) Thesis submitted to Post Graduate Faculty, Skuastk, Shalimar, Kashmir.

Simmons, E.G., 1992. Alternaria taxonomy: current status, viewpoint, challenge. In: Alternaria Biology, Plant Diseases and Metabolites. J. Chelkowski and A. Visconti, eds. Amsterdam, Netherlands:Elsevier Science Publishers, 1-35.

Simmons, E.G., 2007. Alternaria: an Identification Manual. Utrecht, CBS Fungal Diversity Centre.

Tamura, K., Peterson, D., Peterson, N., Stecher, G., Nei, M., Kumar, S., 2011. MEGA5: molecular evolutionary genetics analysis using maximum likelihood, evolutionary distance, and maximum parsimony methods. Molecular Biology and Evolution, 28: 2731-2739.

Udayashankar, A.C., Nayaka, S.C., Archana, B., Anjana, G., Niranjana, S.R., Mortensen, C.N., Lund, O.S., Prakash, H.S., 2012. Specific PCR-based detection of Alternaria helianthi: the cause of blight and leaf spot in sunflower. Archives of Microbiology, 194(11): 923-932.

Waggoner, P.E., Horsfall, J.G., 1969. EPIDEM. A simulator of plant disease written for a computer. Bulletin of the Connecticut Agricultural Experiment Station, New Haven., 698:1-80.

White, T.J., Bruns, T.D., Lee, S., Taylor, J., 1990. Amplification and direct sequencing of fungal ribosomal RNA for phylogentics. In: Innis MA, Gelfland DH, Sninsky JJ, White TJ, eds. PCR Protocols: A guide to methods and applications. San Diego, CA, USA: Academic Press, pp. 315-22. 